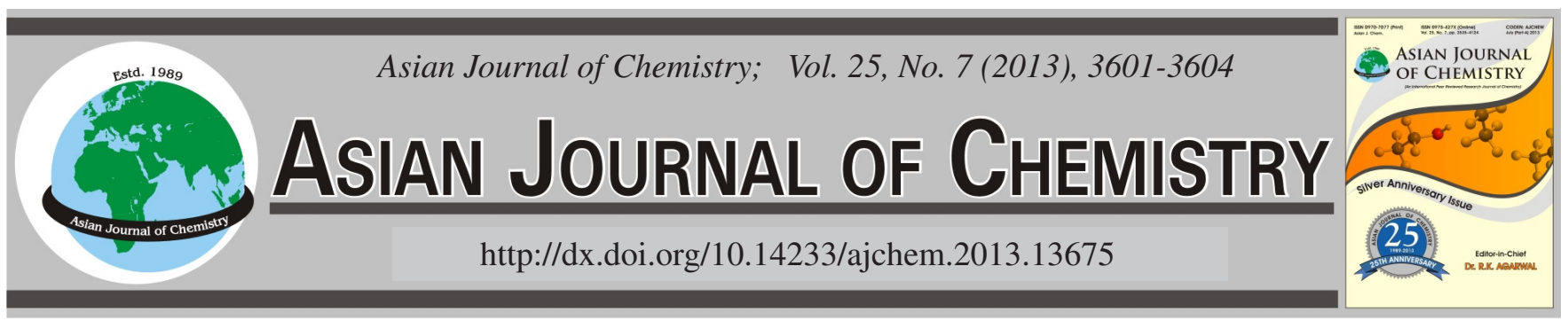

\title{
Study on a New Catalyst Tungsten Phosphide for the Carbon Dioxide Reforming of Methane and Its Preparation Conditions
}

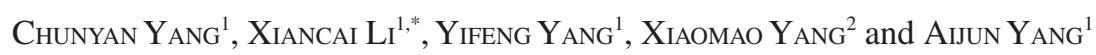

${ }^{1}$ Department of Chemistry, Nanchang University, Nanchang, 330031 Jiangxi, P.R. China

${ }^{2}$ Institute of Applied Materials, Jiangxi University of Finance \& Economics, Nanchang 330013, Jiangxi, P.R. China

*Corresponding author: Fax: +86 791 83969251; Tel: +86 13879110092; E-mail: xcli@ncu.edu.cn; ycysky520@126.com

\begin{abstract}
A new tungsten phosphide was successfully synthesized for the carbon dioxide reforming of methane $\left(\mathrm{CH}_{4}-\mathrm{CO}_{2}\right.$ reforming). The catalysts were prepared by combining citric acid and temperature programmed reduction of phosphotungstate precursor, which was characterized by X-ray diffraction. This paper focuses on investigating that the influence of preparations on activity of tungsten phosphide for $\mathrm{CH}_{4}-\mathrm{CO}_{2}$ reforming. The activity results indicate that the activity and stability of catalyst was prepared under the proper conditions. On this basis, a new easier preparation was proposed, which was prepared by associating calcining with reduction $\mathrm{H}_{3} \mathrm{O}_{40} \mathrm{PW}_{12} \cdot \mathrm{XH}_{2} \mathrm{O}$ and $\left(\mathrm{NH}_{4}\right)_{2} \mathrm{HPO}_{4}$, the prepared catalyst showed a little bit worse of the activity. The activity test results of tungsten phosphide for $\mathrm{CH}_{4}-\mathrm{CO}_{2} \mathrm{reforming}$ show that it produce synthesis gas with lower $\mathrm{H}_{2}$ to $\mathrm{CO}$ ratio than the conventional catalysis for the $\mathrm{CH}_{4}-\mathrm{CO}_{2}$ reforming.
\end{abstract}

Key Words: WP Catalyst, $\mathrm{CH}_{4}-\mathrm{CO}_{2}$ reforming, Preparation, Phosphotungstate.

\section{INTRODUCTION}

Natural gas (the main ingredient is $\mathrm{CH}_{4}$ ) which is increased in the proportion of energy structure of the world year by year. All of the major greenhouse gases have also increased in recent years, especially $\mathrm{CH}_{4}$ and $\mathrm{CO}_{2}$. Therefore, it is significant to do research on their utilization. The reforming of methane with carbon dioxide for the production of synthesis gas $(\mathrm{CO}+$ $\mathrm{H}_{2}$ ) is appealing because it produces synthesis gas with higher purity and lower $\mathrm{H}_{2}$-to- $\mathrm{CO}$ ratio than either partial oxidation or steam reforming ${ }^{1}$. This low ratio of synthesis gas is suitable for the methanol, ammonia and Fischer-Tropsch. On the environmental and energy perspective, both $\mathrm{CH}_{4}$ and $\mathrm{CO}_{2}$ production and utilization could effectively alleviate energy crisis and themselves emission. Thus the $\mathrm{CH}_{4}-\mathrm{CO}_{2}$ reforming is very important ${ }^{2}$.

To select the appropriate catalyst is one of the key factors, which catalyst should to activate and directionally transform small molecular $\mathrm{CH}_{4}$ and $\mathrm{CO}_{2}$. Most of the group VIII elements are known as being activity for $\mathrm{CH}_{4}-\mathrm{CO}_{2}$ reforming, according to Hirose $e t a l{ }^{3}$. The activity order of non-precious metals is $\mathrm{Ni}>\mathrm{Co}>\mathrm{Cu}>\mathrm{Fe}^{4}$. However, the non-precious metals inactivated rapidly during the reforming due to carbon deposition $\left(\right.$ such as nickel ${ }^{5}$ ). Although, the noble metals exhibit not only the characteristics of high transforming activity, but also higher resistance to carbon deposition, whereas they cost too much.
In recent years, scholars have conducted a lot of work to find a suitable way of industrialization in this area, so the issue was deeply studied. Thus, their efforts have been concentrated on how to reduce carbon formation and exploring new nonprecious metal catalysts, which have resistance to carbon deposition, high activity and good stability. Li et al. ${ }^{6}$ have attracted many attentions because of the high activity and good stability of a new molybdenum phosphide (MoP) catalyst for $\mathrm{CH}_{4}-\mathrm{CO}_{2}$ reforming, which prepared by readily available materials and a simple craft. Tungsten and molybdenum with similar chemical and physical properties based on the chromium group and valence electron structure. This report shows how to prepare tungsten phosphide (WP) catalyst by similar methods and measured catalytic activity of $\mathrm{CH}_{4}-\mathrm{CO}_{2}$ reforming, the result showed that the reaction with the as-prepared tungsten phosphide catalyst was stable and efficient.

\section{EXPERIMENTAL}

Preparation tungsten phosphide (I): The tungsten phosphide catalyst was successfully synthesized by using the analytically pure $\left(\mathrm{NH}_{4}\right)_{5} \mathrm{H}_{5}\left[\mathrm{H}_{2}\left(\mathrm{WO}_{4}\right)_{6}\right] \cdot \mathrm{H}_{2} \mathrm{O}$ as tungsten source, $\left(\mathrm{NH}_{4}\right)_{2} \mathrm{HPO}_{4}$ as phosphorus resource, citric acid $(\mathrm{CA})$ as chelator $^{7,8}$. Weighed reactant by molar ratio of $\mathrm{W} / \mathrm{P} / \mathrm{CA}=1: 1: 1$ were dissolved in 30-40 mL of distilled water. Subsequently the solution was aged in a covered beaker in a water bath at $363 \mathrm{~K}$ for $12 \mathrm{~h}$. After a further drying at $393 \mathrm{~K}$ overnight, the 
TABLE-1

PREPARED WP CATALYSTS IN DIFFERENT CONDITIONS

\begin{tabular}{|c|c|c|c|c|c|c|c|c|}
\hline \multirow{2}{*}{ Prepared condition } & \multicolumn{8}{|c|}{ Catalysts } \\
\hline & $\mathrm{A}_{6}$ & $\mathrm{~A}_{8}$ & $\mathrm{~A}_{10}$ & $\mathrm{~A}$ & $\mathrm{~A}_{14}$ & $\mathrm{~A}_{18}$ & $\mathrm{~A}_{24}$ & $\mathrm{~B}$ \\
\hline Aged time (h) & 6 & 8 & 10 & 12 & 14 & 18 & 24 & 12 \\
\hline Environmental & & & & & oclav & & & Constant temperature bath \\
\hline Reactant ratio & & & & & A) $=$ & & & $\mathrm{n}(\mathrm{W}: \mathrm{P}: \mathrm{CA})=1: 1: 1$ \\
\hline
\end{tabular}

sample was calcined at $773 \mathrm{~K}$ for $5 \mathrm{~h}$ in a fluid air and then cooled to room temperature naturally to get the precursor. Some products were taken into U-tube and then reduced by temperature programmed (followed: from room temperature to $573 \mathrm{~K}$ in $0.5 \mathrm{~h}$, after from $573-923 \mathrm{~K}$ at a heating rate of $1 \mathrm{~K} / \mathrm{min}$ and then kept at $923 \mathrm{~K}$ for $2 \mathrm{~h}$ ) in a stream of $\mathrm{H}_{2}$ (purity as $99.999 \%$, velocity as $60 \mathrm{~mL} / \mathrm{min}$ ). Finally, the surface of samples was passivated in a flow of $0.5 \% \mathrm{O}_{2} / \mathrm{He}$ for $12 \mathrm{~h}$.

The prepared tungsten phosphide catalyst was marked as A by above- mentioned method. The tungsten phosphide catalysts were prepared by difference aged time in a covered beaker and they were labeled as: $\mathrm{A}_{6}, \mathrm{~A}_{8}, \mathrm{~A}_{10}, \mathrm{~A}_{14}, \mathrm{~A}_{18}, \mathrm{~A}_{24}$, the number in labels show that the aged time of tungsten phosphide catalysts. The reactive solution was stirred in $363 \mathrm{~K}$ thermostatic water bath for $12 \mathrm{~h}$ instead of autoclave that was mentioned, the prepared tungsten phosphide catalyst was denoted hereafter as B. These catalysts are shown in Table-1.

Preparation of tungsten phosphide (II): A certain amount of phosphotungstic acid $\mathrm{H}_{3} \mathrm{O}_{40} \mathrm{PW}_{12} \cdot \mathrm{XH}_{2} \mathrm{O}$ (PWA) directly calcined in a muffle furnace at $773 \mathrm{~K}$ for $5 \mathrm{~h}$ in air and then cooled to room temperature naturally, then the samples were reduced and passivated in the same way. The prepared tungsten phosphide catalyst was marked as C.

A certain of PWA and $\left(\mathrm{NH}_{4}\right)_{2} \mathrm{HPO}_{4}$, the molar ratio was adjusted to $\mathrm{W}: \mathrm{P}=1: 1$, subsequently, the steps were the same as catalyst $\mathrm{C}$. The formed tungsten phosphide catalyst was denoted as D. The catalysts are shown in Table-2.

\begin{tabular}{lcc}
\multicolumn{3}{c}{ TABLE-2 } \\
TWO DIFFERENT CATALYSTS \\
\cline { 2 - 3 } \multicolumn{1}{c}{ Prepared conditions } & \multicolumn{2}{c}{ Catalyst } \\
\cline { 2 - 3 } & PWA & D \\
\hline Reactant ratio & $\mathrm{PWA}$ and & $\left(\mathrm{NH}_{4}\right)_{2} \mathrm{HPO}_{4} \mathrm{n}(\mathrm{W}: \mathrm{P})=1: 1$ \\
$\begin{array}{l}\text { Pretreatment before } \\
\text { calcination }\end{array}$ & Unmiling & Miling \\
\hline
\end{tabular}

Activity test of catalysts: The amount of catalyst was $150 \mathrm{mg}$, which was taken into U-tube for testing activity of $\mathrm{CH}_{4}-\mathrm{CO}_{2}$ reforming in a fixed bed reactor. Before each test, the catalyst was purged with $\mathrm{N}_{2}(30 \mathrm{~mL} / \mathrm{min})$ at $873 \mathrm{~K}$ for 10 min, then reduced in $\mathrm{H}_{2}(99.999 \%, 60 \mathrm{~mL} / \mathrm{min})$ at $923 \mathrm{~K}$ for $2 \mathrm{~h}$. Finally, the activity tests were carried out at 973, 1023 and $1073 \mathrm{~K}$ with the analytical system (GC $102 \mathrm{M}$ gas-chromatograph, thermal conductivity detector TCD), which reactants were mixture of $\mathrm{CO}_{2}$ and $\mathrm{CH}_{4}$ (the molar ratio $\mathrm{nCH}_{4} / \mathrm{CO}_{2}=$ 1:1) with space velocity of $12000 \mathrm{~mL} /(\mathrm{h} \mathrm{g} \mathrm{cat})$. At the same time, the carrier gas was helium, which velocity as $30 \mathrm{~mL} / \mathrm{min}$.

Stability testing of catalysts: The amount of catalyst also was $150 \mathrm{mg}$. Catalytic stability tests were carried out at 1023 $\mathrm{K}$ in a flow microreactor directly with the analytical system.
The $\mathrm{CH}_{4}-\mathrm{CO}_{2}$ mixture and other conditions of gas-chromatograph were the same as the activity test of catalyst, but the space velocity of mixture adjusted to $6000 \mathrm{~mL} /(\mathrm{h} \mathrm{g}$ cat). The catalysts were also pre-treated in flowing $\mathrm{H}_{2}$ at $923 \mathrm{~K}$ for $2 \mathrm{~h}$.

X-Ray diffraction: Patterns of the intermediates as well as the final samples were determined with a Rigaku diffractometer operated at $40 \mathrm{kV}$ and $100 \mathrm{~mA}$, using $\mathrm{CuK}_{\alpha}$ monochromatized radiation $(\lambda=1.5432 \AA)$.

\section{RESULTS AND DISCUSSION}

Influence of aged time: Catalysts of $\mathrm{A}_{6}, \mathrm{~A}_{8}, \mathrm{~A}_{10}, \mathrm{~A}, \mathrm{~A}_{14}$, $\mathrm{A}_{18}$ and $\mathrm{A}_{24}$ were tested activity for $\mathrm{CH}_{4}-\mathrm{CO}_{2}$ reforming at different temperature, the results are summarized in Table- 3 .

TABLE-3

DIFFERENT CATALYSTS TESTED ACTIVITY FOR $\mathrm{CH}_{4} / \mathrm{CO}_{2}$ REFORMING AT DIFFERENT TEMPERATURES

\begin{tabular}{ccccccc}
\hline \multirow{2}{*}{ Catalyst } & \multicolumn{6}{c}{ Conversion (\%) } \\
\cline { 2 - 7 } & \multicolumn{2}{c}{$973 \mathrm{~K}$} & \multicolumn{2}{c}{$1023 \mathrm{~K}$} & \multicolumn{2}{c}{$1073 \mathrm{~K}$} \\
\cline { 2 - 7 } & $\mathrm{CH}_{4}$ & $\mathrm{CO}_{2}$ & $\mathrm{CH}_{4}$ & $\mathrm{CO}_{2}$ & $\mathrm{CH}_{4}$ & $\mathrm{CO}_{2}$ \\
\hline $\mathrm{A}_{6}$ & 40.3 & 94.8 & 63.2 & 97.6 & 76.1 & 98.3 \\
$\mathrm{~A}_{8}$ & 44.4 & 94.6 & 64.7 & 96.7 & 88.8 & 1.0 \\
$\mathrm{~A}_{10}$ & 42.9 & 93.3 & 44.5 & 95.2 & 54.6 & 96.1 \\
$\mathrm{~A}$ & 43.8 & 99.5 & 55.0 & 98.2 & 70.0 & 96.8 \\
$\mathrm{~A}_{14}$ & 38.2 & 78.4 & 40.3 & 91.5 & 43.1 & 95.7 \\
$\mathrm{~A}_{18}$ & 46.5 & 88.5 & 60.6 & 91.6 & 81.5 & 94.8 \\
$\mathrm{~A}_{24}$ & 33.2 & 80.8 & 43.1 & 82.3 & 49.9 & 90.1 \\
\hline
\end{tabular}

Table- 3 shows that the catalytic activity of $A_{8}$ the same as $\mathrm{A}_{18}$ at different experimental temperature, but better than other five kinds of catalysts. The phenomenon suggests that aged time has some effect on the catalytic activity. If the catalysts of weak activity were prepared, maybe the reactants were not responded at all in the short aged time. If the aged time was too long, maybe the prepared catalysts had week activity at higher temperature due to poor antisintering.

Table-3 also shows that their activity increased in varying degrees with the raising of aged temperature. The catalytic activity can be improve by the endothermic reaction of $\mathrm{CH}_{4}$ $\mathrm{CO}_{2}$ reforming on the one hand (temperature ascending is favour of thermodynamic equilibrium) and the number of active center is increasing as the surface of tungsten phosphide precursors, which is reduced gradually to tungsten phosphide on the other hand. But, higher tempe-rature would cause high energy consumption.

Stability of $\mathbf{A}_{\mathbf{8}}$ and $\mathbf{A}_{\mathbf{1 8}}$ : The tungsten phosphide catalysts were prepared by different aged time in a covered beaker. The catalyst of $A_{8}$ and $A_{18}$ were measured the stability for $12 \mathrm{~h}$. The results are shown in Fig. 1, in which the $\mathrm{A}_{18}$ catalyst showed a better stability. The $\mathrm{A}_{8}$ catalyst was no longer to be tested because of its low activity after $5 \mathrm{~h}$ test. $\mathrm{A}_{8}$ catalyst was not stable due to lack of aged time and the aged was inadequate. 
TABLE-4

ACTIVITY OF A AND B CATALYSTS IN DIFFERENT ENVIRONMENT

\begin{tabular}{|c|c|c|c|c|c|c|c|}
\hline \multirow{2}{*}{$\begin{array}{c}\text { Reaction } \\
\text { temperature } \mathrm{T}(\mathrm{K})\end{array}$} & \multirow{2}{*}{ Sample } & \multicolumn{2}{|c|}{ Conversion $(\%)$} & \multicolumn{4}{|c|}{ Composition of products and reactants $(\%)$} \\
\hline & & $\mathrm{CH}_{4}$ & $\mathrm{CO}_{2}$ & $\mathrm{CH}_{4}$ & $\mathrm{CO}_{2}$ & $\mathrm{CO}$ & $\mathrm{H}_{2}$ \\
\hline \multirow{2}{*}{927} & A & 38.4 & 99.5 & 33.1 & 0.2 & 49.2 & 17.6 \\
\hline & $\mathrm{B}$ & 41.2 & 97.4 & 31.5 & 1.2 & 45.9 & 21.4 \\
\hline \multirow{2}{*}{1023} & A & 55.0 & 98.2 & 24.1 & 0.8 & 46.1 & 29.0 \\
\hline & $\mathrm{B}$ & 56.6 & 98.0 & 23.3 & 0.9 & 43.5 & 32.3 \\
\hline \multirow{2}{*}{1093} & $\mathrm{~A}$ & 70.1 & 96.8 & 16.1 & 1.5 & 46.9 & 35.5 \\
\hline & B & 78.6 & 99.1 & 11.5 & 0.4 & 46.5 & 41.6 \\
\hline
\end{tabular}

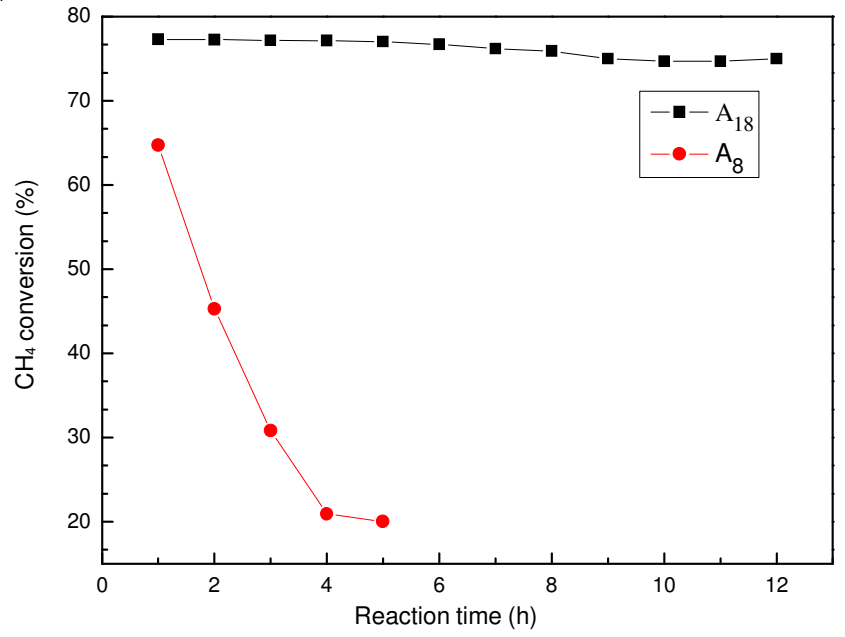

Fig. 1. Stability tests of $\mathrm{A}_{8}$ and $\mathrm{A}_{18}$ catalysts

Influence of aged environment: The performance of the catalysts (A and $\mathrm{B}$ ) was measured in $\mathrm{CH}_{4}-\mathrm{CO}_{2}$ reforming at different temperatures. The results are shown in Table-4. Table-4 shows that the activity of catalyst B are better than A at different experimental temperatures. It maybe due to the aged was more fully in $363 \mathrm{~K}$ constant temperature water bath and stirring than in the autoclave.

Influence of preparation methods: The performance of the catalysts $\left(\mathrm{C}\right.$ and $\mathrm{D}$ ) in $\mathrm{CH}_{4}-\mathrm{CO}_{2}$ reforming was tested at different temperatures. The test results were compared with the catalytic activity of $\mathrm{A}_{18}$ (Table-5). Table-4 showed that the catalytic activity was related to proportion of $\mathrm{P}$ element in tungsten phosphide and the catalyst has good activity when the molar ratio of $\mathrm{W}: \mathrm{P}=1: 1$ from the current experimental tests (such as $\mathrm{D}$ and $\mathrm{A}_{18}$ catalyst). The activity of $\mathrm{D}$ catalyst is similar to that of $A_{18}$. However, preparation of $\mathrm{D}$ catalyst was easier than $\mathrm{A}_{18}$. This is a suitable way of industrialization.

\begin{tabular}{|c|c|c|c|c|c|c|c|}
\hline \multicolumn{8}{|c|}{$\begin{array}{c}\text { TABLE-5 } \\
\text { ACTIVITY OF A } A_{18}, \text { C AND D CATALYSTS } \\
\text { PREPARED BY DIFFERENT METHODS }\end{array}$} \\
\hline \multirow{2}{*}{$\begin{array}{l}\text { Reaction } \\
\text { temp. T } \\
\text { (K) }\end{array}$} & \multirow{2}{*}{ Sample } & \multicolumn{2}{|c|}{$\begin{array}{l}\text { Conversion } \\
(\%)\end{array}$} & \multicolumn{4}{|c|}{$\begin{array}{l}\text { Composition of products } \\
\text { and reactants }(\%)\end{array}$} \\
\hline & & $\mathrm{CH}_{4}$ & $\mathrm{CO}_{2}$ & $\mathrm{CH}_{4}$ & $\mathrm{CO}_{2}$ & $\mathrm{CO}$ & $\mathrm{H}_{2}$ \\
\hline \multirow{3}{*}{973} & A18 & 46.5 & 88.5 & 27.6 & 5.4 & 45.2 & 21.8 \\
\hline & C & 44.9 & 78.8 & 29.5 & 9.8 & 42.5 & 18.2 \\
\hline & D & 45.3 & 99.1 & 29.3 & 0.4 & 47.1 & 23.1 \\
\hline \multirow{3}{*}{1023} & A18 & 60.6 & 91.6 & 21.2 & 3.9 & 44.2 & 30.7 \\
\hline & C & 57.1 & 96.6 & 23.0 & 1.6 & 41.2 & 34.2 \\
\hline & $\mathrm{D}$ & 65.9 & 97.1 & 18.3 & 1.4 & 46.0 & 34.3 \\
\hline \multirow{3}{*}{1073} & A18 & 81.5 & 94.8 & 9.9 & 2.4 & 45.7 & 42.0 \\
\hline & C & 70.7 & 95.1 & 15.7 & 2.3 & 42.4 & 39.6 \\
\hline & D & 76.1 & 96.0 & 12.8 & 1.9 & 47.9 & 37.4 \\
\hline
\end{tabular}

Specially, the synthesis gas produced by these catalysts had lower $\mathrm{H}_{2}$ to $\mathrm{CO}$ ratio than the conventional catalysts for the $\mathrm{CH}_{4}-\mathrm{CO}_{2}$ reforming did, which was detected from Tables $3-5$. The reason was that could be caused by the process $\left(\mathrm{CO}_{2}\right.$ $+\mathrm{H}_{2} \rightarrow \mathrm{CO}+\mathrm{H}_{2} \mathrm{O}$ ) and the side reaction more likely occurred by the WP catalyst.

X-ray powder diffraction analysis: The prepared products $\left(\mathrm{A}_{18}, \mathrm{C}\right.$ and $\left.\mathrm{D}\right)$ were characterized by powder $\mathrm{X}$-ray diffraction (Fig. 2). As expected, the catalysts $A_{18}$ and $D$ have characteristic diffraction peaks of tungsten phosphide (PDF291364) crystalline phase, which were measured $2 \theta$ degree for $21.1,28.7,31.1,43.2,44.6,46.5,68.8$ and $73.8^{\circ}$ end so on, respectively. However, the patterns of D catalyst shows that its crystal was formed weekly because of lower calcined temperature and there was the tungsten phosphide oxide $\left(\mathrm{WOPO}_{4}\right)$ (PDF44-0348) diffraction peaks also detected from this pattern and the $2 \theta$ degree for $15.9,21.7,23.1,33.2,36.4,40.5,49.6$ and $55.3^{\circ}$ etc., respectively. The reason was that may be the nanophases $\mathrm{WOPO}_{4}$ formed in the calcination stage of the reactants and did not reduce at the TPR of phosphotungstate precursor stage. So the activity of $\mathrm{A}_{18}$ catalyst was better than that of $\mathrm{D}$ catalyst. Obviously, the $\mathrm{C}$ catalyst have characteristic diffraction peaks of $\mathrm{W}$ (PDF47-1319) and the $2 \theta$ degree for $35.5,39.9,43.9,63.8,66.7,69.6,86.0$ and $88.7^{\circ}$ etc., respectively. The reason is that the $\mathrm{C}$ catalyst was prepared directly by the PWA. Obviously, the molar ratio of $\mathrm{P} / \mathrm{W}$ was 1:12 from chemical formula of the $\mathrm{H}_{3} \mathrm{O}_{40} \mathrm{PW}_{12} \cdot \mathrm{XH}_{2} \mathrm{O}$ and the content of $\mathrm{W}$ element is higher than tungsten phosphide in the product after reduction. So there were no evidently tungsten phosphide different peaks detected, except the $2 \theta$ degree for 49.9, 63.9, 73.8 and $85.8^{\circ}$. The appearance of $\mathrm{WO}_{3}$ diffraction peaks (PDF46-1096) because of the C catalyst exposed to the air resulting in the partially oxidized of the surface. Thus, the catalytic activity of $\mathrm{D}$ catalyst is higher than that of $\mathrm{C}$ catalyst for the $\mathrm{CH}_{4}-\mathrm{CO}_{2}$ reforming. This is consistent with the experimental results. Reported in the literature, the $\mathrm{W}$ element for $\mathrm{CO}_{2}$ reforming of $\mathrm{CH}_{4}$ has no activity ${ }^{9}$.

\section{Conclusion}

The tungsten phosphide with activity in $\mathrm{CH}_{4}-\mathrm{CO}_{2}$ reforming was successfully prepared by temperature programmed reduction of amorphous phosphotungstate. In the view of current experiment, the tungsten phosphide with good activity and stability was prepared by stirring for $18 \mathrm{~h}$ in $363 \mathrm{~K}$ thermostatic water bath and also can obtain directly by calcining and reduction of the $\mathrm{H}_{3} \mathrm{O}_{40} \mathrm{PW}_{12} \cdot \mathrm{XH}_{2} \mathrm{O}$ and di-ammonium hydrogen phosphate. The activity test results of tungsten phosphide for $\mathrm{CH}_{4}-\mathrm{CO}_{2}$ reforming show that it products synthesis gas produced by this method had lower $\mathrm{H}_{2}$ to $\mathrm{CO}$ ratio than the conventional catalysts for the $\mathrm{CH}_{4}-\mathrm{CO}_{2}$ reforming did, which could be caused by the process $\left(\mathrm{CO}_{2}+\mathrm{H}_{2} \rightarrow \mathrm{CO}+\mathrm{H}_{2} \mathrm{O}\right)$. 


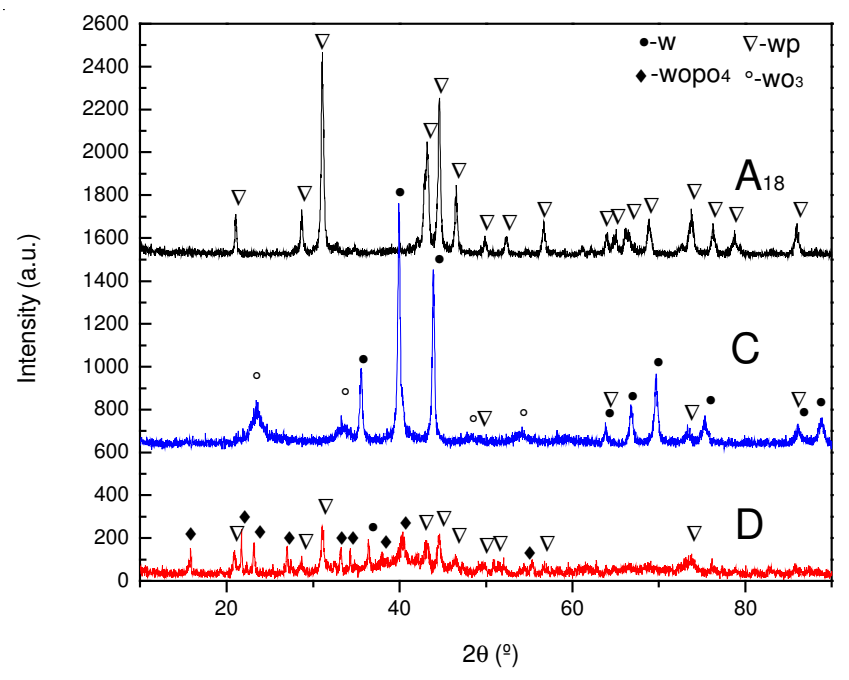

Fig. 2. Powder XRD patterns of $A_{18}, C$ and $D$

\section{ACKNOWLEDGEMENTS}

This work was supported by a grant from the National Natural Science Foundation of China (21063010).

\section{REFERENCES}

1. J. Huang, R.X. Ma, T. Huang, A.R. Zhang and W. Huang, J. Nat. Gas Chem., 465, 20 (2011)

2. R.Q. Yang, C. Xing, C.X. Lv, L. Shi and N. Tsubaki, Appl. Catal. A, 92, 385 (2010).

3. T. Hirose, Y. Ozawa and M. Nagai, Chin. J. Catal., 32, 771 (2011).

4. O. Tokunaga and S. Ogasawara, React. Kinet. Catal. Lett., 39, 69, (1989).

5. J.R. Rostrup-Nielsen and J.H. Bak Hansen, J. Catal., 38, 144 (1993).

6. X.C. Li, A.J. Yang and C.Y. Yang, Chinese Patent 10240276.9 ( 2010).

7. R.H. Cheng, Y.Y. Shu, L. Li, M.Y. Zheng, X.D. Wang, A.Q. Wang and T. Zhang, Appl. Catal. A: Gen., 160, 316 (2007).

8. R.H. Cheng, N. Li, M.Y. Zheng, L. Li, X.D. Wang and T. Zhang, Chin. J. Catal., 31, 26 (2005).

9. F. Fischer and H. Tropscii, Brennstoff Chem., 39, 3 (1928). 